\title{
IMPLEMENTATION OF DISTRIBUTED AVERAGE CONSENSUS METHOD ON WIRELESS SENSOR NETWORK FOR MONITORING TEMPERATURE AND HUMIDITY IN SWITCHGEAR ROOM
}

\author{
Mohamad Tri Aziz Budi Cahyono Putro \\ Department of Electrical Engineering, Faculty of Engineering, University of Muhammadiyah Gresik \\ triaziz.moh@gmail.com
}

\begin{abstract}
The development of wireless sensor networks is currently very rapid in various sectors. One of the implementations of the wireless sensor network is for monitoring temperature and humidity. In monitoring a room or a large area, many nodes are installed at a certain point. With the number of senses by each node so that one data that can represent the area is needed. To get one data that can represent the data in that area, we need a consensus method. In this study, the average distributed consensus method was used to obtain data representation from an area's wireless sensor network. After testing and simulating the ideal range between WSN nodes is $\mathbf{3 0}$ meters where the average percentage of detection errors reaches $0 \%$. And the maximum capacity is 33 meters with an average percentage of error detection of $46 \%$. If given a barrier between WSN nodes, the distance that can be reached becomes shorter, with an ideal distance of 16 meters with an average percentage of error detection of $0 \%$ and the farthest distance reaching 21 meters with a detection error of $50 \%$. The results of the consensus method simulation show that the more slots are filled with consensus data about the results, the faster and easier convergence will be achieved, in this case, the monitoring results represent the real situation.
\end{abstract}

Keywords: Internet of Thing (IOT), Average Distributed Consensus Method, Convergent, Wireless Sensor Networks.

\section{INTRODUCTION}

Most companies must have a switchgear room as the distribution panel. Switchgear is a distribution panel that distributes the load to panels with smaller capacities. In the switchgear room, an HVAC (Heating Ventilation \& Air Conditioning) system is needed or good air conditioning to maintain temperature and humidity. The Air Conditioning System or AHU / HVAC plays an important role in maintaining the air condition in the Switchgear room so that it is following existing procedures to avoid short circuits or short circuits, errors in the equipment in it and so on [1].

Communication systems used in temperature and humidity monitoring have many models and implementations, such as research from [2] which discusses making applications for monitoring and controlling room temperature that can be applied to rooms such as laboratories and server rooms using computer hardware, microcontrollers and SMS-based gateway. However, the output generated from this research is only in the form of room temperature monitoring applications. Meanwhile in research by Denny and Soviatul [3] discusses monitoring of temperature and humidity using a microcontroller-based SMS gateway which is implemented in an incubator in the tempe fermentation room. Supposedly to get more accurate results can be added methods in the data processing system. The problems in the research that have been mentioned above are the basis for the development of the temperature and humidity monitoring system, so in this study, the development of a temperature and humidity monitoring and control system is proposed for the maintenance of distribution panels in the switchgear room with an average distributed consensus method system.

\section{LITERATURE REVIEW}

\section{Switchgear Room}

Switchgear is a distribution panel that distributes the load to panels that are smaller in capacity. In Indonesian it means Medium Voltage Panel (PTM) or also called MVMDB (Medium Voltage Main Distribution Board) and while for low 
voltage it is called LVMDB (Low Voltage Main Distribution Board). Based on research [4] in the electrical power system, switchgear is broadly defined as the connecting components/breakers and their supports in an integrated unit, so that they can function as a connector, breaker, and protector of the two sides of the circuit.

\section{HVAC System / Air Conditioning}

The Air Conditioning System or more commonly known as AHU (Air Handling Unit) or HVAC (Heating, Ventilating, and Air Conditioning) is a system that conditions the environment through controlling temperature, relative humidity, the direction of air movement and air quality, including particle control and exhaust. Airborne contaminants such as vapors and fumes. AHU consists of several machines/tools each has different functions, which are integrated to form an air conditioning system that can control temperature, humidity, air pressure, level of cleanliness, airflow patterns, and the number of air changes according to predetermined procedures.

\section{Wireless Sensor Network (WSN)}

A sensor is a tool that functions to convert physical quantities into other physical quantities such as electricity. A set of sensors that communicate wirelessly using a Personal Area Network (PAN) is known as a Wireless Sensor Network or what is known as a Wireless Sensor Network (WSN) [5].

\section{Hardware}

The hardware (Hardware) that will be used in this research includes a processing unit that uses an Arduino type UNO microcontroller, LoRa as a transceiver device, a sensor device using a DHT11 sensor, 2x16 LCD as a display output and an LED as an output actuator.

\section{Calculation BER System}

Bit Error Rate (BER) is a key parameter used to assess the performance of a system that sends digital data from one location to another. In digital transmission, BER is the rate at which errors occur in transition systems. The calculation of BER in the communication system is based on the probability process of the amount of data received against the transmitted data. Based on [6] BER is presented in equation (1)

$$
B E R=\frac{\text { Data not accepted }}{\text { Total data sent }} \times 100
$$

\section{Simulation With Matlab}

MATLAB is a program package with a high programming language for developing algorithms, data visualization, and numerical computation. This MATLAB program can be used to solve computational problems faster than traditional programming languages, such as $\mathrm{C}, \mathrm{C}++$, and Fortran. MATLAB is used for many applications such as signal and image processing, control design, testing and measurement, modeling, and analysis [7].

\section{Average Distributed Consensus Method}

The consensus mean method is a variant of the consensus method on the WSN. The consensus method allows the data obtained by each sensor node to be updated iteratively by data from its neighboring sensor nodes.

This study discusses a communication system that uses a distributed average consensus method where this method is developed with a multi-agent system. This consensus is an important aspect of coordination and cooperation between nodes. The average consensus method is a linear iteration scheme where each value that is updated by each node is a linear weighted combination of the value obtained by itself and the value received from neighboring nodes [8].

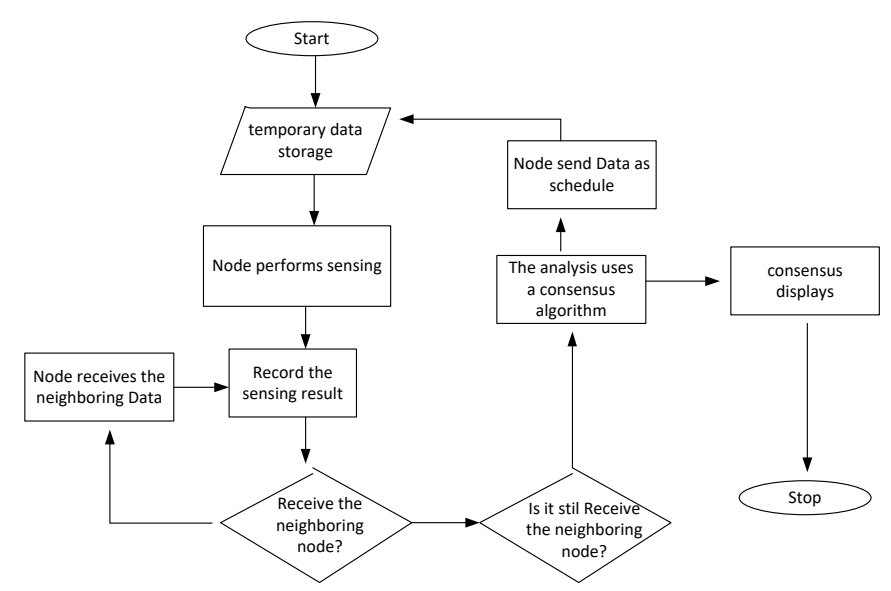

Figure 1. The flow of the WSN System Using the Consensus Method

\section{RESULT AND DISCUSSION}

This research will conduct trials and analysis which includes 3 stages, the first stage is the trial of the WSN node design, the second is the simulation of the average distributed consensus method using the MatLab and the third is the trial of the average distributed consensus method directly using a prototype of the WSN node.

The node design trial is a test that is carried out concerning the performance of the designed WSN node. From a series of WSN node design trials, it was concluded that the ideal range between nodes when there are no obstacles/disturbances is 30 meters where the average percentage of detection errors reaches $0 \%$. However, if you look at the maximum capacity, the 
furthest distance is 33 meters with an average percentage of error detection of $46 \%$. However, if there is a barrier/interference, the coverage distance of the WSN node will decrease, that is, the ideal distance between nodes that can be achieved if given a barrier is 16 meters where the average percentage of detection errors reaches $0 \%$. However, if you look at the maximum capacity, the furthest distance is 21 meters with an average percentage of detection errors of $50 \%$.

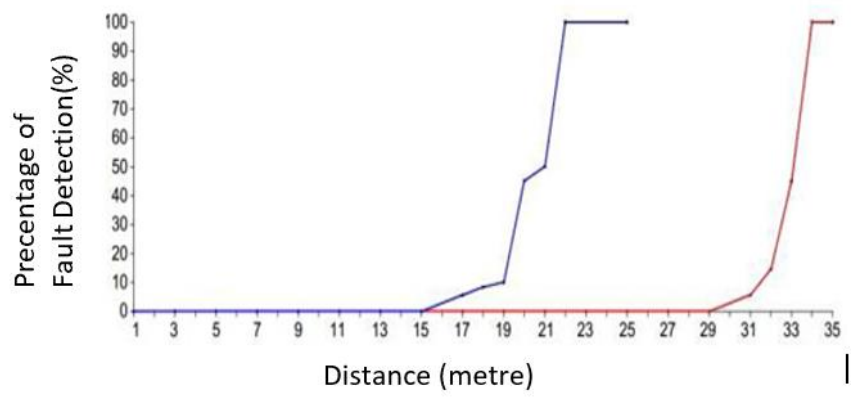

Figure 2. Graph of the Average Percentage of Detection Error

In Table 3.1. the red line shows the results of the WSN node range test results if there is no barrier, while the blue grid shows the results of the WSN node range testing using a barrier/interference, from the graph above explains that the farther the distance you reach, the greater the error achieved.

After testing the design of the WSN node then next simulation using MATLAB, Average consensus method testing done by simulating the algorithm as in figure 2.1 by taking different temperature data values for each sensor namely Node $1=28$, Node $2=29$, Node $3=30$ and Node $4=31$ then it is obtained graph of simulation results for a weight of 0.1 up to 0.9 as in Figure 3
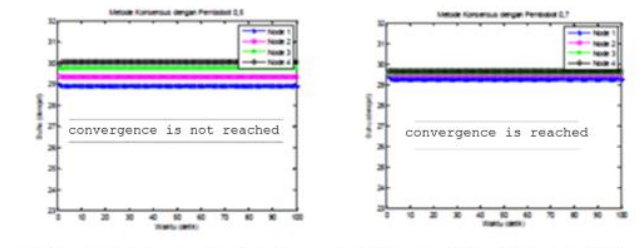

a weight of 0.5, namely 10 slots for a weight of 0.7 , namely 6 slots for
sensing and 10 slots for neighboring nodes
sensing and 10 slots for neighboring nodes

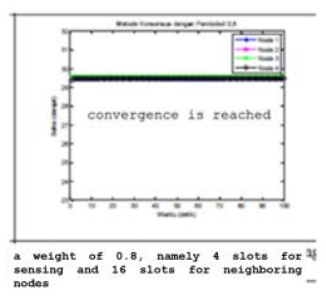

Figure 3. Consensus Method Simulation Distributed Average
Figure. 3. explains that on weighting 0.5 convergence has not been reached, new convergence is reached at the weight 0.7 . The fastest convergence time from among weights of 0.7 to 0.9 is reached when using a weight of 0.8 , namely with a convergence time of 1 second with the consensus result temperature was $29.5^{\circ} \mathrm{C}$.

The final stage is to test try directly using the prototype node WSN. The 4 equipped WSN nodes are used with temperature and humidity sensors as well good communication skills transmit and receive, in terms of the consensus method the weight parameter is set to 0.8 and from in terms of sensors calibrated with standard hygrometer as a reference.

The test was carried out at temperature closed room at 19.00. First The air conditioner in the room is turned off and waiting up to 10 minutes later the temperature was observed in the room. Then the AC turned back on temperature $30^{\circ} \mathrm{C}$ at the first 5 minutes, then in the next 5 minutes $21^{\circ} \mathrm{C}$ and $16^{\circ} \mathrm{C}$ in the next 5 minutes. So it is $1 \mathrm{x}$ test try takes observation 15 minute.

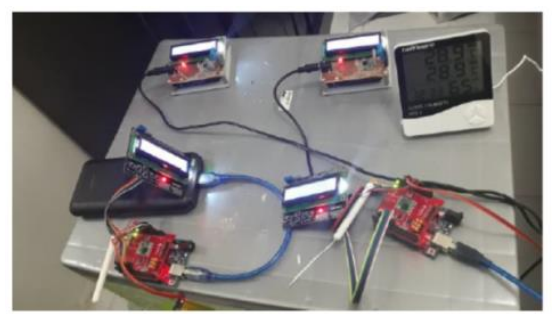

Figure 4. Trial Using WSN Node Prototype

Figure 4. shows the test activities try directly using the prototype node WSN. After a series of trials was carried out hence the results of direct trials using the prototype node WSN is as shown in Table 1

Table 1. Direct Trial Results

\begin{tabular}{|c|c|c|c|c|c|c|c|c|}
\hline \multirow[b]{2}{*}{$\begin{array}{c}\text { Percobaan } \\
\mathrm{Ke}\end{array}$} & \multirow[b]{2}{*}{ Waktu } & \multirow{2}{*}{\begin{tabular}{|c|} 
Waktu \\
Kouvergensi
\end{tabular}} & \multicolumn{3}{|c|}{ Data Subu } & \multicolumn{3}{|c|}{ Data Kelembaban } \\
\hline & & & $\begin{array}{c}\text { Hygrometer } \\
\text { Standard } \\
\end{array}$ & $\begin{array}{c}\text { Data } \\
\text { Konsensus } \\
\end{array}$ & $\begin{array}{c}\text { Kesalahan } \\
\%\end{array}$ & \begin{tabular}{c|} 
Hygrometer \\
Standard \\
Sal
\end{tabular} & \begin{tabular}{|c|} 
Data \\
Konsensus \\
\end{tabular} & $\begin{array}{c}\text { Kesalahau } \\
\%\end{array}$ \\
\hline \multirow{3}{*}{1} & $\begin{array}{l}5 \text { Menit Pertama } \\
\text { (30 Celcins) }\end{array}$ & 10 & 27,7 & 26 & 1,7 & 60 & 57 & 3 \\
\hline & $\begin{array}{l}5 \text { 5enit Kedua } \\
\text { (21 Celcus) }\end{array}$ & 14 & 26,7 & 25 & 1,7 & 59 & 56 & 3 \\
\hline & $\begin{array}{l}5 \text { Menit Ketiga } \\
\text { (16 Cetcius) }\end{array}$ & 10 & 26 & 24 & 2 & 57 & 55 & 2 \\
\hline \multirow{3}{*}{2} & $\begin{array}{l}5 \text { Menit Pertama } \\
\text { (30 Celcius) }\end{array}$ & 13 & 27.8 & 27 & 0.8 & 65 & 63 & 2 \\
\hline & $\begin{array}{l}5 \text { Menit Kedua } \\
\text { (21 Celcius) }\end{array}$ & 14 & 26,5 & 26 & 0,5 & 64 & 62 & 2 \\
\hline & $\begin{array}{l}5 \text { Menit Ketiga } \\
\text { (16 Celcius) }\end{array}$ & 10 & 26 & 24 & 2 & 60 & 58 & 2 \\
\hline \multirow{3}{*}{3} & $\begin{array}{l}5 \text { Menit Pertamaa } \\
\text { (30 Celcius) }\end{array}$ & 12 & 27.2 & 27 & 0.2 & 62 & 59 & 3 \\
\hline & $\begin{array}{l}5 \text { SMent Kedtua } \\
\text { (21 Celcius) }\end{array}$ & 14 & 26,9 & 26 & 0,9 & 65 & 63 & 2 \\
\hline & $\begin{array}{l}\text { 5Menit Ketiga } \\
\text { (16 Ceckus) }\end{array}$ & 11 & 26,8 & 25 & 1,8 & 60 & 56 & 4 \\
\hline \multirow{3}{*}{4} & $\begin{array}{l}5 \text { Menit Pertama } \\
\text { (30 Celcius) }\end{array}$ & 10 & 27,4 & 27 & 0.4 & 69 & 65 & 4 \\
\hline & $\begin{array}{l}5 \text { Menit Kedua } \\
\text { (21 Celcius) }\end{array}$ & 12 & 26.9 & 26 & 0.9 & 65 & 65 & 0 \\
\hline & $\begin{array}{l}5 \text { Ment Ketiga } \\
\text { (16 Cedcius) }\end{array}$ & 14 & 26,3 & 25 & 1,3 & 60 & 58 & 2 \\
\hline \multirow{3}{*}{5} & $\begin{array}{l}5 \text { Menit Pertama } \\
\text { (30 Celcuus) }\end{array}$ & 14 & 27,2 & 27 & 0,2 & 67 & 66 & 1 \\
\hline & $\begin{array}{l}5 \text { Menit Kedua } \\
\text { (21 Celcius) }\end{array}$ & 12 & 26,5 & 26 & 0.5 & 65 & 63 & 2 \\
\hline & $\begin{array}{l}5 \text { Menit Ketiga } \\
\text { (16 Celcus) }\end{array}$ & 14 & 26 & 24 & 2 & 63 & 62 & 1 \\
\hline \multicolumn{2}{|c|}{$\begin{array}{l}\text { Rata-Rata Waktu } \\
\text { Kouvergeusi }\end{array}$} & 12 & \multicolumn{2}{|c|}{$\begin{array}{l}\text { Rata-rata Prosentase } \\
\text { Kesalaban \% }\end{array}$} & 1,13 & \multicolumn{2}{|c|}{$\begin{array}{l}\text { Rata-rata Prosentase } \\
\text { Kesalahan \% }\end{array}$} & 2,20 \\
\hline
\end{tabular}


From table 1. it is obtained conclusion where the average time convergence is 12 seconds with the percentage of temperature error is $1.13 \%$ and $2.20 \%$ humidity error. From the results table 1 convergence time requires time not more than 1 minute. Therefore, the remaining 5 minutes ( 1 st to 5 th minute) are used for the stability test. The stability of the convergence data is observed every minute. While the results obtained from this trial are the percentage of stability. The results of the convergence stability observations are as shown in table 2.

The percentage of stability is calculated from the number of majority temperature data divided by the overall temperature data $\mathrm{x} 100 \%$. For example in the first experiment in the second 5 minutes, 4 times the temperature data reaches $24{ }^{\circ} \mathrm{C}$ while 1 time reaches $25^{\circ} \mathrm{C}$. If the temperature data is 5 , then the percentage of stability is $4 / 5 \times 100 \%=80 \%$. From table 2 , it can be concluded that the percentage of temperature stability ranges from $60 \%$ to $100 \%$ and humidity stability ranges from $60 \%$ to $80 \%$.

Table 2. Stability Test Results

\begin{tabular}{|c|c|c|c|c|c|c|c|c|c|c|c|c|}
\hline \multirow{2}{*}{$\begin{array}{c}\begin{array}{c}\text { Percobaan } \\
\text { Ke- }\end{array} \\
\end{array}$} & \multirow{2}{*}{ Waktu } & \multicolumn{5}{|c|}{ Data Subu Pada Menit Ke- } & \multirow{2}{*}{\begin{tabular}{c|}
$\begin{array}{c}\text { Kestabilau } \\
(\%)\end{array}$ \\
\end{tabular}} & \multicolumn{5}{|c|}{ Data Kelembabau Pada Menit Ke- } \\
\hline & & 1 & 2 & 3 & 4 & 5 & & 1 & 2 & 3 & 4 & 5 \\
\hline \multirow{3}{*}{ 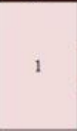 } & $\begin{array}{c}5 \text { Menit Pertama } \\
\text { (30 Celcius) }\end{array}$ & 27 & 27 & 27 & 27 & 27 & 100 & 64 & 63 & 63 & 64 & 64 \\
\hline & $\begin{array}{l}5 \text { Menit Kedua } \\
\text { (21 Celcicus) }\end{array}$ & 25 & 24 & 24 & 24 & 24 & 80 & 62 & 62 & 60 & 60 & 60 \\
\hline & $\begin{array}{l}5 \text { Menit Ketiga } \\
\text { (16 Celcius) }\end{array}$ & 24 & 24 & 24 & 24 & 24 & 100 & 59 & 58 & 58 & 58 & 58 \\
\hline \multirow{3}{*}{2} & $\begin{array}{l}5 \text { Menit Pertama } \\
\text { (30 Celcius) }\end{array}$ & 27 & 26 & 27 & 27 & 27 & 80 & 63 & 63 & 63 & 64 & 63 \\
\hline & $\begin{array}{l}5 \text { Menit Kedua } \\
\text { (21 Celcius) }\end{array}$ & 26 & 26 & 26 & 26 & 25 & 80 & 57 & 57 & 56 & 56 & 56 \\
\hline & $\begin{array}{c}5 \text { Menit Ketiga } \\
\text { (16 Celchus) }\end{array}$ & 24 & 25 & 24 & 25 & 25 & 60 & 55 & 54 & 55 & 54 & 54 \\
\hline \multirow{3}{*}{3} & $\begin{array}{c}5 \text { Menit Pertama } \\
\text { (30 Celcius) }\end{array}$ & 26 & 26 & 26 & 26 & 26 & 100 & 63 & 63 & 63 & 61 & 61 \\
\hline & $\begin{array}{l}5 \text { Menit Kedua } \\
\text { (21 Celcins) }\end{array}$ & 26 & 26 & 26 & 26 & 25 & 80 & 61 & 61 & 60 & 60 & 60 \\
\hline & $\begin{array}{l}5 \text { Menit Ketiga } \\
\text { (16 Celcius) }\end{array}$ & 24 & 24 & 24 & 24 & 24 & 100 & 56 & 56 & 56 & 55 & 55 \\
\hline \multirow{3}{*}{4} & $\begin{array}{l}5 \text { Menit Pertama } \\
\text { (30 Celcius) }\end{array}$ & 26 & 26 & 26 & 26 & 26 & 100 & 66 & 66 & 67 & 67 & 67 \\
\hline & $\begin{array}{l}5 \text { Menit Kedua } \\
\text { (21 Celcicus) }\end{array}$ & 26 & 26 & 26 & 26 & 25 & 80 & 64 & 64 & 62 & 62 & 62 \\
\hline & $\begin{array}{l}5 \text { Menit Ketiga } \\
\text { (16 Celcins) }\end{array}$ & 25 & 24 & 24 & 25 & 25 & 60 & 57 & 57 & 56 & 56 & 56 \\
\hline \multirow{3}{*}{5} & $\begin{array}{c}5 \text { Menit Pertama } \\
\text { (30 Celcius) }\end{array}$ & 26 & 26 & 26 & 25 & 26 & so & 65 & 65 & 64 & 65 & 65 \\
\hline & $\begin{array}{l}5 \text { Menit Kedua } \\
\text { (21 Celcius) }\end{array}$ & 26 & 26 & 26 & 26 & 26 & 100 & 62 & 62 & 61 & 61 & 61 \\
\hline & $\begin{array}{c}5 \text { Menit Ketija } \\
\text { (16 Ceclaus) }\end{array}$ & 24 & 24 & 24 & 24 & 24 & 100 & 56 & 56 & 56 & 55 & 55 \\
\hline
\end{tabular}

\section{CONCLUSION}

The consensus method is a method that is suitable for making decisions to determine a value between several sensing data from different nodes. From the results of experiments and simulations, it can be concluded: In measuring the range without obstructions/disturbances, the ideal range of nodes is $30 \mathrm{~m}$ where the average percentage of detection errors reaches $0 \%$. However, if you look at the maximum capacity, the furthest distance is 33 meters with an average percentage of detection errors of $46 \%$.

In measuring the range using a barrier/interference, the range of the node is 16 meters where the average percentage of detection errors is $0 \%$. However, if you look at the maximum capacity, the furthest distance is 21 meters with an average percentage of detection errors of $50 \%$. The simulation test of the distributed average consensus method shows that the more memory is allocated for data from neighboring nodes, the easier and faster convergence will be achieved.

\section{REFERENCES}

[1] Priyambodo, Bambang. 2014. Sistem Tata Udara (AHU/HVAC) https://priambodo1971.wordpress.com/cpob/sarana-penunjang-kritisindustri-farmasi/sistem-tata-udara-ahuhvac/. Diakses pada tanggal 10 April 2019.

[2] Hakim, Brahmanto, dan Syahri. 2010. Aplikasi Monitoring Suhu Ruangan Berbasis Komputer dan SMS Gateway. Jurnal Informatika Mulawarman. Vol.5 No.3.

[3] Wijanarko, Hasanah. 2017. Monitoring Suhu dan Kelembaban Menggunakan SMS Gateway Pada Proses Fermentasi Tempe Secara Otomatis Berbasis Mikrokontroler. Jurnal Informatika Polinema. Vol.4 Edisi 1.

[4] Rusli, Andi. 2011. Standar Operasi dan Standart Pemeliharaan Switvhgear

http://wwwpabriksawitcom.blogspot.com/2011/05/switchgear.html. Diakses pada tanggal 10 April 2019.

[5] Sandeep, Patalay. 2012. Railway Signalling Using Wireless Sensor Networks Sr.IT Engineer, CMC Ltd.

[6] Misbah et al. Communication System on Wireless Sensor Networks using Rasberry Pi and Arduino for Monitoring Gas of Air Pollution. in Internationl Seminar Intelligent Technology on Its Application, Denpasar, Bali, 44, p. 39.

[7] Cleve Moler. 2004. The Creator of MATLAB The Origins of MATLAB.

http://www.mathworks.com/company/newsletters/news_notes/clevesco rnr/dec04.html. Diakses pada tanggal 10 April 2019.

[8] Terdistribusi pada WSN, http://belajar-WSN.blogspot.co.id, p. 1, 11. Diakses pada tanggal 10 April 2019. 